\title{
PENGARUH MODEL PEMBELAJARAN KONSTRUKTIVISME TERHADAP HASIL BELAJAR FISIKA SISWA SMP NEGERI 10
}

\author{
Nidya Eka Putri, I Wayan Darmadi dan Muhammad Ali \\ e-mail: Nidya_ekaputri@ymail.com \\ Program Studi Pendidikan Fisika FKIP Universitas Tadulako \\ Jl. Soekarno Hatta Km. 9 Kampus Bumi Tadulako Tondo Palu - Sulawesi Tengah
}

\begin{abstract}
Abstrak - Penelitian ini bertujuan untuk melihat pengaruh model pembelajaran konstruktivisme terhadap hasil belajar fisika siswa pada kelas IX di SMP Negeri 10 Palu. Jenis penelitian yang digunakan adalah eksperimen kuasi dengan desain "Nonequivalent Control Group Design". Sampel dipilih dengan menggunakan teknik purposive sampling dan menghasilkan kelas IX A sebagai kelas eksperimen dan kelas IX B sebagai kelas kontrol. Instrumen yang digunakan berupa tes hasil belajar dalam bentuk pilihan ganda. Rerata skor tes hasil belajar berdasarkan hasil pengolahan data, diperoleh rerata skor pretest kelas eksperimen adalah 6,90 dan untuk posttest adalah 13,00. Untuk kelas kontrol diperoleh rerata skor pretest 6,30 sedangkan untuk posttest adalah 12,00 Analisis data tes dilakukan dengan teknik statistik uji-t satu pihak untuk menguji perbedaan rerata skor hasil belajar siswa dengan taraf signifikansi $\alpha=0,05$. Diperoleh nilai hasil $t_{\text {hitung }}=2,47$ dan $t_{\text {tabel }}=$ 1,67 . Ini berarti bahwa nilai $t_{\text {hitung }}>t_{\text {tabel }}$ sehingga dapat disimpulkan Ho ditolak. Kemudian berdasarkan uji $\mathrm{N}$ gain diperoleh peningkatan hasil belajar sebesar $55 \%$ atau berada di kategori sedang. Dengan demikian dapat disimpulkan bahwa, terdapat pengaruh model pembelajaran konstruktivisme terhadap hasil belajar.
\end{abstract}

Kata Kunci : Model Pembelajaran Konstruktivisme, Hasil Belajar Fisika.

\section{PENDAHULUAN}

Pendidikan pada hakekatnya adalah usaha sadar untuk mengembangkan kepribadian dan kemampuan di dalam dan diluar sekolah. Pendidikan berperan penting dalam meningkatkan kualitas sumber daya manusia yang mendukung kemajuan pembangunan. Kualitas pendidikan MIPA merupakan salah satu yang perlu mendapat perhatian, karena menjadi dasar bagi perkembangan ilmu pengetahuan dan teknologi (IPTEK).

Fisika adalah bagian dari sains, pada hakikatnya adalah kumpulan pengetahuan, cara berpikir, dan penyelidikan. Pembelajaran fisika sangat berkaitan dengan cara mencari tahu tentang fenomena alam secara sistematis, sehingga pembelajaran fisika bukan hanya sekedar penguasaan kumpulan pengetahuan yang berupa fakta-fakta, konsep-konsep, atau prinsip-prinsip saja tetapi juga merupakan suatu proses penemuan.

Keberhasilan proses pembelajaran IPA khususnya fisika di sekolah sangat dipengaruhi oleh latar belakang budaya yang dimiliki oleh siswa atau masyarakat tempat sekolah berada. Latar belakang budaya yang dimiliki siswa (student's prior belief and knowledge) kemudian digunakan dalam kelas selama proses pembelajaran berlangsung memainkan peran yang sangat penting pada proses penguasaan konsep. Latar belakang budaya yang dibawa oleh guru dan siswa ke dalam kelas (terutama pada saat pembelajaran fisika) sangat menentukan dalam penciptaan atau pengkondisian suasana belajar dan mengajar yang bermakna dan berkonteks.

Ketika merencanakan dan menyiapkan kegiatan pembelajaran, guru perlu mempertimbangkan pengalaman dan konsep yang dimiliki siswa. Depdiknas [1] dari pengalaman, konsep awal yang telah dimiliki siswa yang tidak sesuai dengan konsep ilmiah sangat sulit dibenahi atau dibetulkan. Terlebih bila konsep yang telah dimiliki itu berguna dalam kehidupan nyata dan tidak akan berubah hanya dengan pembelajan konvensional misalnya ceramah. Maka dianjurkan untuk menggunakan cara mengajar baru yang lebih menantang pengetahuan siswa. Cara baru itu harus dapat menimbulkan pertanyaan pada siswa, menimbulkan keraguan dalam pikirannya dan kebingungan terhadap konsep awal yang dipegangnya. Suparno [2]

Penelitian yang dilakukan Hapsari [3] menyatakan bahwa dalam pelajaran IPA pendekatan konstruktivisme dapat meningkatkan hasil belajar dan keaktifan siswa dalam proses belajar mengajar. Di samping itu 
pembelajaran membagun konstruktivisme, siswa menemukan langkah-langkah dalam mencari penyelesaian dari suatu materi yang harus dikuasai oleh siswa.

Pembelajaran konstruktivisme memberi siswa kesempatan untuk berpikir tentang pengalamannya. Ini dapat mendorong siswa berpikir kreatif, imajinatif, mendorong refleksi tentang model dan teori, mengenalkan gagasan-gagasan pada saat yang tepat.

Mengacu pada uraian diatas tujuan penelitian yaitu untuk mengetahui ada tidaknya pengaruh model pembelajaran konstruktivisme terhadap hasil belajar fisika pada siswa SMP Negeri 10 Palu.

\section{METODOLOGI PENELITIAN}

Penelitian menggunakan metode penelitian kuasi eksperimen. Tujuan penelitian yang menggunakan kuasi eksperimen adalah untuk memperoleh informasi yang merupakan perkiraan bagi peneliti yang dapat diperoleh melalui eksperimen sebenarnya dalam keadaan yang tidak memungkinkan untuk mengontrol dan atau memanipulasi semua variabel yang relevan.

Desain yang digunakan dalam penelitian adalah "Nonequivalent control group design". Menurut Sugiono [5] Desain ini hampir sama dengan pretest-posttest control group design hanya pada desain ini kelompok eksperimen maupun kelompok kontrol tidak dipilih secara random. Desain dapat digambarkan sebagai berikut:

Tabel 1 : Nonequivalent control group design
\begin{tabular}{|c|c|c|c|}
\hline Kelompok & Pre-test & Treatment & Posttest \\
\hline Eksperimen & $\mathrm{O}_{1}$ & $\mathrm{X}$ & $\mathrm{O}_{2}$ \\
\hline Kontrol & $\mathrm{O}_{1}$ & - & $\mathrm{O}_{2}$ \\
\hline
\end{tabular}

Keterangan:

$\mathrm{O}_{1} \quad$ : Pretest (kelompok eksperimen)

$\mathrm{O}_{2} \quad$ : Posttest (kelompok eksperimen)

$\mathrm{O}_{1} \quad$ : Pretest (kelompok kontrol)

$\mathrm{O}_{2}$ : Posttest (kelompok kontrol)

$\mathrm{X}$ : Perlakuan dengan model pembelajaran konstruktivisme

Penelitian dilaksanakan di SMP Negeri 10

Palu. Kelas IX A dengan jumlah siswa 26 orang dan kelas IX B dengan jumlah siswa 26 orang yang mengikuti mata pelajaran fisika tahun ajaran 2014/2015. Penelitian dilakukan mulai pada bulan Oktober 2014 sampai dengan bulan Desember 2014.

Berdasarkan hasil validitas ahli, pada awalnya terdiri dari 30 item soal kemudian disetujui sebanyak 28 item soal yang diuji cobakan. Kedua puluh delapan item soal ini sebelumnya telah divalidasi oleh ahli kemudian dikoreksi dan disesuaikan dengan tujuan pembelajaran yang ingin dicapai. Soal-soal tersebut selanjutnya diuji cobakan pada siswa dari sekolah lain yang telah menerima materi tersebut dan mempunyai kemampuan yang sama dengan sekolah yang akan diteliti. Selanjutnya dilakukan analisis berdasarkan validitas item, tingkat kesukaran dan daya pembeda sebagai berikut :

\section{Uji Validitas Tes}

Berdasarkan hasil uji coba, selanjutnya dilakukan analisis berdasarkan validitas item, tingkat kesukaran dan daya pembeda. Pada validitas item soal dengan nomor $1,2,3,4,7$, $8,10,11,12,15,17,18,20,21,22,23,25$, 26 , dan 28. dianalisis dengan menggunakan tes berada pada kategori sedang sampai dengan sangat tinggi dimana koefisien korelasinya berada pada rentang $(0,41-1,00)$.

Indeks Kesukaran

Hasil analisis indeks kesukaran atau tingkat kesukaran soal-soal yang dapat diterima yaitu yang berada pada kategori sedang yaitu soal dengan nomor $1,2,4,5,7$, $8,9,10,11,12,15,16,18,19,20,21,22,24$, $25,26,27,28$ dengan nilai indeks kesukaran berada pada rentang $(0,31-0,70)$.

\section{Daya Pembeda}

Selanjutnya untuk hasil analisis daya pembeda, soal-soal yang mempunyai daya pembeda butir soal yang dapat diterima yaitu berada pada kategori cukup sampai baik sekali atau yang berada pada rentang $(0,20-0,40)$ yaitu soal denga nomor $1,2,4,8,10,12,15$, $17,18,20,23,25,26,28$.

\section{Reliabilitas}

Setelah dilakukan analisis berdasarkan validitas item, tingkat kesukaran dan daya pembeda, selanjutnya dilakukan analisis berdasarkan reliabilitas tes. Suatu tes dikatakan reliabel jika $r_{11}>0,70$ dan nilai reliabilitas tes $\left(r_{11}\right)$ yang diperoleh dari hasil penelitian ini sebesar 0,75 . 
Hal ini menunjukkan bahwa nilai reliabilitas tes hasil perhitungan lebih besar dibandingkan nilai reliabilitas tes yang ditentukan. Berdasarkan hasil tes tersebut diketahui bahwa tes hasil belajar fisika siswa yang disusun dapat memberikan hasil yang tepat, atau mempunyai taraf kepercayaan yang tinggi. Dengan kata lain, sejauh mana suatu tes dapat dipercaya untuk menghasilkan skor yang tetap, relatif tidak berubah walaupun diteskan pada situasi yang berbeda-beda.

Berdasarkan hasil di atas, dari 28 item soal yang diuji cobakan pada siswa kelas IX A, soal yang memenuhi syarat untuk digunakan sebagai tes hasil belajar siswa adalah sebanyak 18 item.

\section{HASIL DAN PEMBAHASAN}

\section{Deskripsi Hasil Pretest}

Tabel 2 :Deskripsi skor tes hasil belajar fisika kelas eksperimen dan kelas kontrol (Pretest).

\begin{tabular}{|l|c|c|}
\hline \multicolumn{1}{|c|}{ Deskripsi } & $\begin{array}{c}\text { Kelas IX A } \\
\text { (Eksperimen) }\end{array}$ & $\begin{array}{c}\text { Kelas IX B } \\
\text { (Kontrol) }\end{array}$ \\
\hline Jumlah Siswa & 26 & 26 \\
\hline Skor Minimum & 3 & 2 \\
\hline Skor Maksimum & 12 & 13 \\
\hline Skor Rata-rata & 6,9 & 6,3 \\
\hline Standar Deviasi & 2,1 & 2,7 \\
\hline
\end{tabular}

\section{Uji Normalitas}

Tabel 3 : Hasil Uji Normalitas Prettest Kelas Eksperimen dan Kelas Kontrol

\begin{tabular}{|c|l|c|c|c|}
\hline No & \multicolumn{1}{|c|}{ Kelas } & $\begin{array}{c}\text { Nilai } \\
X^{2} \text { Hitung }\end{array}$ & $\begin{array}{c}\text { Nilai } \\
X^{2} \text { tabel }\end{array}$ & Keputusan \\
\hline 1 & Eksperimen & 4,58 & & $\begin{array}{c}\text { Terdistribusi } \\
\text { normal }\end{array}$ \\
\cline { 1 - 3 } 2 & kontrol & 2,28 & & $\begin{array}{c}\text { Terdistribusi } \\
\text { normal }\end{array}$ \\
\hline
\end{tabular}

Uji normalitas pada penelitian ini menggunakan uji Chi-kuadrat dengan kriteria penerimaan $\chi_{\text {Hitung }}^{2}<\chi_{\text {tabel, }}^{2}$ taraf signifikansi $\alpha$ $=0,05$ dan derajat kebebasan $\mathrm{dk}=\mathrm{k}-3$. Berdasarkan hasil uji normalitas pada Tabel 3. diketahui nilai $\chi_{\text {Hitung }}^{2}<\chi_{\text {tabel }}^{2}$ atau $\chi_{\text {Hitung }}^{2}$ untuk kelas eksperimen dan kelas kontrol lebih kecil dibandingkan nilai $\chi_{\text {tabel. Dimana untuk kelas }}^{2}$ eksperimen $4,58<7,81$ dan untuk kelas kontrol 2,28<7,81. Sesuai kriteria pengambilan keputusan, maka baik data dari kelas eksperimen maupun kelas kontrol keduanya berasal dari populasi yang terdistribusi normal.

\section{Uji Homogenitas}

Uji homogenitas pada penelitian menggunakan uji statistik $F$ dengan taraf signifikansi $\alpha=0,05$ dan nilai varians kelas eksperimen sebesar 5,13 serta kelas kontrol sebesar 6,69. Berdasarkan hasil perhitungan,

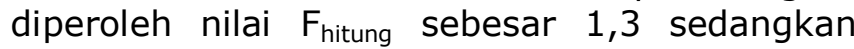
nilai $F_{\text {tabel }}$ sebesar 1,98. Berdasarkan hasil uji homogenitas pada Tabel 4.3, diketahui nilai $F_{\text {hitung }}$ lebih kecil dibandingkan dengan nilai $F_{\text {tabel. }}$. Dengan kata lain $F_{\text {hitung }}<F_{\text {tabel }}$ atau $\left.\mathrm{F}_{\mathrm{o}}<\mathrm{F} \alpha_{(\mathrm{v} 1}, \mathrm{v} 2\right)$, secara matematis dapat dituliskan $1,3<1,98$. Berdasarkan kriteria pengambilan keputusan, diketahui data tersebut memiliki varians yang sama atau homogen. Artinya, tidak terdapat perbedaan varians antara kelas eksperimen maupun kelas kontrol.

\section{Deskripsi Hasil Posttest}

Tabel 4 : Deskripsi skor tes hasil belajar fisika kelas eksperimen dan kelas kontrol untuk soal pilihan ganda (posttest).

\begin{tabular}{|l|c|c|}
\multicolumn{1}{|c|}{ Deskripsi } & $\begin{array}{c}\text { Kelas IX A } \\
\text { (Eksperimen) }\end{array}$ & $\begin{array}{c}\text { Kelas IX B } \\
\text { (Kontrol) }\end{array}$ \\
\hline Jumlah Siswa & 26 & 26 \\
\hline Skor Minimum & 8 & 7 \\
\hline Skor Maksimum & 18 & 17 \\
\hline Skor Rata-rata & 13,00 & 11,00 \\
\hline Standar Deviasi & 3,00 & 2,80 \\
\hline
\end{tabular}

\section{Uji Normalitas}

Tabel 5 : Hasil Uji Normalitas Posttes Kelas Eksperimen dan Kelas Kontrol

\begin{tabular}{|c|l|c|c|c|}
\hline No & \multicolumn{1}{|c|}{ Kelas } & $\begin{array}{c}\text { Nilai } \\
\chi_{\text {Hitung }}^{2}\end{array}$ & $\begin{array}{c}\text { Nilai } \\
\chi_{\text {tabel }}^{2}\end{array}$ & Keputusan \\
\hline 1 & Eksperimen & 7,61 & \multirow{2}{*}{7,81} & $\begin{array}{c}\text { Terdistribusi } \\
\text { normal }\end{array}$ \\
\cline { 2 - 3 } 2 & Kontrol & 2,04 & $\begin{array}{c}\text { Terdistribusi } \\
\text { normal }\end{array}$ \\
\hline
\end{tabular}

Uji normalitas pada penelitian menggunakan uji Chi-kuadrat dengan kriteria penerimaan $\chi_{\text {Hitung }}^{2}<\chi_{\text {tabel, taraf signifikansi } \alpha}^{2}$ $=0,05$ dan derajat kebebasan $\mathrm{dk}=\mathrm{k}-3$. Berdasarkan hasil perhitungan, nilai $\chi_{\text {Hitung }}^{2}$ kelas eksperimen adalah sebesar 7,61, untuk kelas kontrol sebesar 2,04 $\chi_{\text {tabel }}^{2} 7,81$. Berdasarkan hasil uji normalitas pada Tabel 5 . diketahui nilai $\chi_{\text {Hitung }}^{2}<\chi_{\text {tabel }}^{2}$ atau $\chi_{\text {Hitung }}^{2}$ untuk kelas eksperimen dan kelas kontrol lebih kecil dibandingkan nilai $\chi_{\text {tabel. Dimana untuk kelas }}^{2}$ eksperimen $7,61<7,81$ dan untuk kelas kontrol $2,28<7,81$. Sesuai kriteria pengambilan keputusan, maka baik data dari kelas eksperimen maupun kelas kontrol 
keduanya berasal dari populasi yang terdistribusi normal.

\section{Uji Homogenitas}

$\mathrm{Uji}$ homogenitas pada penelitian menggunakan $u j i$ statistik $F$ dengan taraf signifikansi $\alpha=0,05$ dan nilai varians kelas eksperimen sebesar 7,34 serta kelas kontrol sebesar 8,32. Berdasarkan hasil perhitungan, diperoleh nilai $F_{\text {hitung }}$ sebesar 1,13 sedangkan nilai $F_{\text {tabel }}$ sebesar 1,98. Berdasarkan hasil uji homogenitas pada Tabel 4.7, diketahui nilai $F_{\text {hitung }}$ lebih kecil dibandingkan dengan nilai $F_{\text {tabel. }}$. Dengan kata lain $F_{\text {hitung }}<F_{\text {tabel }}$ atau $\left.\mathrm{F}_{\mathrm{o}}<\mathrm{F} \alpha_{(\mathrm{v} 1}, \mathrm{v} 2\right)$, secara matematis dapat dituliskan $1,3<1,98$. Berdasarkan kriteria pengambilan keputusan, diketahui data tersebut memiliki varians yang sama atau homogen. Artinya, tidak terdapat perbedaan varians antara kelas eksperimen maupun kelas kontrol.

\section{Uji Hipotesis (Uji-t) Posttest}

Berdasarkan nilai rata-rata posttest kelas eksperimen sebesar 13,00 dan kelas kontrol sebesar 11.00, dilakukan uji hipotesis (uji-t) beda rata-rata (satu pihak) dan diketahui nilai $t_{\text {hitung }}=2,47$. Selanjutnya untuk nilai $t_{\text {tabel }}=t_{(1-}$ a) pada taraf nyata $\mathrm{a}=0,05$ dan $\mathrm{dk}=\left(\mathrm{n}_{1}+\mathrm{n}_{2}\right.$ $-2)=26+26-2=50$, diperoleh $t_{0,95(50)}=$ 1,67 . Diketahui $t_{\text {hitung }} \geq t_{\text {tabel }}$ atau $2,47 \geq 2,00$. Dengan demikian $\mathrm{H}_{0}$ ditolak dan $\mathrm{H}_{1}$ diterima sehingga dapat disimpulkan bahwa rata-rata hasil belajar antara siswa yang mendapatkan pembelajaran menggunakan model pembelajaran konstruktivisme lebih tinggi daripada siswa yang mendapatkan pembelajaran menggunakan model konvensional.

\section{Uji N-Gain}

Untuk mengetahui peningkatan hasil belajar yang diperoleh pada kelas eksperimen yang menggunakan model pembelajaran konstruktivisme maupun kelas control yang menggunakan pembelajaran konvensional dihitung berdasarkan skor N-gain. Berdasarkan skor $\mathrm{N}$-gain yang diperoleh di kelas eksperimen maupun kelas control, skor $\mathrm{N}$ gain kelas Eksperimen $=55 \%$ dan kelas Kontrol $=40,17 \%$ sehingga dapat disimpulkan bahwa berdasarkan data kualitatif skor $\mathrm{N}$ gain kelas eksperimen maupun kelas kontrol berada dikriteria sedang dengan kata lain terdapat peningkatan hasil belajar pada kedua kelas. Namun berdasarkan data kuantitatif skor $\mathrm{N}$-gain pada kelas eksperimen lebih besar daripada skor $\mathrm{N}$-gain kelas kontrol dengan kata lain peningkatan hasil belajar lebih besar dikelas eksperimen dengan menggunakan model pembelajaran konstruktivisme daripada kelas kontrol dengan pembelajaran konvensional

\section{Pembahasan}

Berdasarkan penelitian yang dilakukan dengan menggunakan model pembelajaran konstruktivisme, kemampuan awal siswa berdasarkan pemberian tes awal (pretest) diperoleh besar pencapaian skor rata-rata pada kelas eksperimen yaitu 6,9 sedangkan pada kelas kontrol yaitu 6,3. Untuk tes akhir (posttest) besar pencapaian skor rata-rata pada kelas eksperimen yaitu sebesar 13 sedangkan pada kelas kontrol yaitu 11. Hasil menunjukkan adanya perbedaan skor antara kedua kelas, Terlihat skor untuk kelas eksperimen lebih tinggi dibandingkan kelas kontrol. Berdasarkan data yang diperoleh tersebut, kemudian dilakukan analisis terhadap normalitas serta homogenitas varians. Hasilnya baik data pretes maupun posttest keduanya berdistribusi normal dan memiliki varians yang homogen.

Berdasarkan analisis kuantitatif data posttest, diketahui nilai rata-rata kelas eksperimen lebih besar dibandingkan dengan nilai rata-rata kelas control. Perbedaan antara rerata skor posttest kelas eksperimen dan kelas kontrol menunjukkan adanya pengaruh model pembelajaran yang diterapkan pada kedua kelas tersebut. Pengaruh yang signifikan terjadi pada kelas eksperimen. Kelas eksperimen menggunakan model pembelajaran konstruktivisme pada model pembelajarannya sedangkan kelas kontrol menggunakan model konvensional. Setelah dilakukan uji normalitas dan homogenitas varians, selanjutnya dilakukan uji hipotesis dengan menggunakan uji-t dua pihak berdasarkan hasil skor pretest dan skor posttest.

Berdasarkan hasil skor posttest pada masing-masing kelas telah diberikan perlakuan, diperoleh nilai $t_{\text {hitung }}=2,47$ dan nilai $t_{\text {tabel }}=$ 1,67. Dimana $H_{0}$ ditolak jika $\mathrm{t} \geq \mathrm{t}_{(1-\mathrm{a})}$, diketahui hipotesis $\mathrm{H}_{0}$ ditolak dan hipotesis satu $\left(\mathrm{H}_{1}\right)$ diterima. Artinya rata-rata hasil belajar antara kelas yang mendapatkan pembelajaran menggunakan model pembelajaran konstruktivisme lebih tinggi daripada kelas yang mendapatkan pembelajaaran menggunakan model konvensional.

Pada penelitian juga kita menggunakan Uji peningkatan hasil belajar atau $\mathrm{N}$-gain yaitu untuk mengetahui peningkatan hasil belajar 
yang diperoleh pada kelas eksperimen yang menggunakan model pembelajaran konstruktivisme maupun kelas kontrol yang menggunakan model konvensional. Skor $\mathrm{N}$ gain yang diperoleh dikelas Eksperimen $=55 \%$ dan dikelas Kontrol $=40,17 \%$ sehingga dapat disimpulkan bahwa berdasarkan data kualitatif skor $\mathrm{N}$ gain kelas eksperimen maupun kelas kontrol berada di kriteria sedang dengan kata lain terdapat peningkatan hasil belajar pada kedua kelas. Namun berdasarkan data kuantitatif skor $\mathrm{N}$-gain pada kelas eksperimen lebih besar daripada skor $\mathrm{N}$-gain kelas kontrol dengan kata lain peningkatan hasil belajar lebih besar dikelas eksperimen dengan menggunakan model pembelajaran konstruktivisme daripada kelas kontrol dengan pembelajaran konvensional.

Kondisi dalam proses pembelajaran yang terjadi sebelum di terapkannya model pembelajaran konstruktivisme dalam kelas eksperimen maupun kelas kontrol adalah sama, karena siswa hanya berfokus pada guru, sehingga siswa menjadi kurang aktif. Setelah diterapkannya model pembelajaran konstruktivisme, terjadilah perbedaan tes hasil belajar terutama pada kelas eksperimen.

Perbedaan tersebut disebabkan oleh proses pembelajaran menggunakan model pembelajaran konstruktivisme memiliki tahapan tahapan pembelajaran yaitu pertama orientasi dan elicitasi ide dimana pada proses ini untuk memotivasi siswa dalam mengawali proses pembelajaran dan melalui elicitasi siswa mengungkapkan idenya dengan berbagai cara sehingga dalam tahapan ini dapat menjadikan siswa lebih aktif mengemukakan ide-ide atau pengetahuan-pengetahuan yang telah diperoleh sebelum masuk kedalam kelas. Tahapan yang kedua yaitu Restrukturisasi ide dimana dalam tahapan ini siswa diberikan kesempatan untuk menyelidiki dan menemukan konsep atau permasalahan melalui kerja kelompok untuk membahas kemudian mendiskusikan temuannya dengan kelompok lain, sehingga secara keseluruhan pada tahap ini siswa memecahkan masalah dan terlibat langsung dalam proses pembelajaran dimana informasi dan pengetahuan mereka temukan secara mandiri dari lingkungan maupun dari dalam kelas, saling berinteraksi bukan hanya dengan guru tetapi juga dengan teman mereka dan dengan begitu dapat memenuhi rasa keingintahuan tentang topik pelajaran yang dibahas pada saat itu. Kemudian pada tahap ketiga yaitu aplikasi yaitu menerapkan pengetahuan yang telah dipelajari, sehingga pada tahapan ini siswa lebih tertarik untuk belajar karena pengetahuan yang diperoleh dapat diterapkan dalam kehidupa sehari hari. Tahap terakhir yaitu Review yaitu mengadakan tinjauan kembali apabila masih terdapat kesalahan dam menerapkan pengetahuan tersebut. Sehingga secara keseluruhan Model pembelajaran konstruktivisme yang digunakan membuat siswa menjadi lebih aktif dalam menyelesaikan masalah dan menerapkan ilmu fisika dalam kehidupan sehari-hari, sehingga hasil belajar dan kemampuan penemuan siswa secara individu maupun kelompok dapat meningkat.

Hasil penelitian yang telah dilakukan telah sesuai dengan penelitian yang dilakukan oleh Ramadhani [6] yang menyatakan bahwa model pembelajaran konstruktivisme dapat meningkatkan hasil belajar siswa.

\section{KESIMPULAN}

Berdasarkan hasil analisa data penelitian, maka dapat disimpulkan bahwa terdapat pengaruh model pembelajaran konstruktivisme terhadap hasil belajar fisika siswa SMP N 10 Palu. Hal ini dapat diketahui melalui hasil pengujian $\mathrm{N}$-gain (uji peningkatan hasil belajar) sebesar $55 \%$ dan pengujian hipotesis dengan menggunkan uji-t pada tes akhir memberikan hasil nilai thitung yang lebih besar dari $t_{\text {tabel }}$ yaitu $t_{\text {hitung }}=2,47>t_{\text {tabel }} 1,67$ pada taraf nyata 0,05

\section{DAFTAR PUSTAKA}

[1] Depdiknas (2004). Sains Buku 1. Jakarta.

[2] Suparno, P. (2005). Miskonsepsi dan Perubahan Konsep Pendidikan. Grasindo, Jakarta

[3] Hapsari, R.T.S. (2011). Penerapan model Pembelajaran konstruktivisme Untuk meningkatkan Hasil Belajar IPA. Jurnal Pendidikan Penabur

[4] Ali, M. (1993). Strategi Penelitian Pendidikan. Bandung: Angkasa

[5] Sugiono (2008) Metode Penelitian Pendidikan. Bandung: Alfabeta.

[6] Ramadhani. N (2012) "Pengaruh Model Pembelajaran Kontruktivis 5E Terhadap Hasil Belajar di SMA Laksamana Martadinata". Jurnal Pendidikan Fisika. ISSN 2252-732x. 